\title{
Tracing carbon assimilation in endosymbiotic deep-sea hydrothermal vent Mytilid fatty acids by ${ }^{13} \mathrm{C}$-fingerprinting
}

\author{
V. Riou ${ }^{1,2}$, S. Bouillon ${ }^{1,3}$, R. Serrão Santos ${ }^{2}$, F. Dehairs ${ }^{1}$, and A. Colaço ${ }^{2}$ \\ ${ }^{1}$ Department of Analytical and Environmental Chemistry, Vrije Universiteit Brussel, Brussels, Belgium \\ ${ }^{2}$ Department of Oceanography and Fisheries, IMAR-University of Azores, Horta, Portugal \\ ${ }^{3}$ Department of Earth and Environmental Sciences, Katholieke Universiteit Leuven, Leuven, Belgium
}

Received: 4 May 2010 - Published in Biogeosciences Discuss.: 10 May 2010

Revised: 8 July 2010 - Accepted: 25 August 2010 - Published: 2 September 2010

\begin{abstract}
Bathymodiolus azoricus mussels thrive at MidAtlantic Ridge hydrothermal vents, where part of their energy requirements are met via an endosymbiotic association with chemolithotrophic and methanotrophic bacteria. In an effort to describe phenotypic characteristics of the two bacterial endosymbionts and to assess their ability to assimilate $\mathrm{CO}_{2}, \mathrm{CH}_{4}$ and multi-carbon compounds, we performed experiments in aquaria using ${ }^{13} \mathrm{C}$-labeled $\mathrm{NaHCO}_{3}$ (in the presence of $\mathrm{H}_{2} \mathrm{~S}$ ), $\mathrm{CH}_{4}$ or amino-acids and traced the incorporation of ${ }^{13} \mathrm{C}$ into total and phospholipid fatty acids (tFA and PLFA, respectively). 14:0; 15:0; 16:0;16:1(n-7)c+t; $18: 1(n-13) c+t$ and $(n-7) c+t ; 20: 1(n-7) ; 20: 2(n-9,15)$; $18: 3(n-7)$ and $(n-5,10,13)$ PLFA were labeled in the presence of $\mathrm{H}^{13} \mathrm{CO}_{3}^{-}\left(+\mathrm{H}_{2} \mathrm{~S}\right)$ and ${ }^{13} \mathrm{CH}_{4}$, while the 12:0 compound became labeled only in the presence of $\mathrm{H}^{13} \mathrm{CO}_{3}^{-}$ $\left(+\mathrm{H}_{2} \mathrm{~S}\right)$. In contrast, the 17:0; 18:0;16:1(n-9); 16:1(n-8) and $(n-6) ; 18: 1(n-8)$; and 18:2(n-7) PLFA were only labeled in the presence of ${ }^{13} \mathrm{CH}_{4}$. Some of these symbiontspecific fatty acids also appeared to be labeled in mussel gill tFA when incubated with ${ }^{13} \mathrm{C}$-enriched amino acids, and so were mussel-specific fatty acids such as $22: 2(n-7,15)$. Our results provide experimental evidence for the potential of specific fatty acid markers to distinguish between the two endosymbiotic bacteria, shedding new light on $\mathrm{C}_{1}$ and multicarbon compound metabolic pathways in B. azoricus and its symbionts.
\end{abstract}

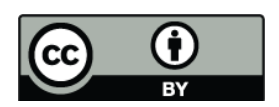

Correspondence to: V. Riou (virginie_riou@hotmail.com)

\section{Introduction}

Deep-sea hydrothermal vents host peculiar ecosystems fueled by methane, sulfide, iron or even hydrogen (e.g., Perner et al., 2009). The symbiotic association of bacteria with marine invertebrate hosts provides the former with access to the chemical substrates necessary for their metabolism and the latter with a source of organic carbon (and nitrogen). One of the two species of endosymbiotic bathymodioline Mytilids occurring along the Mid-Atlantic Ridge (MAR), Bathymodiolus azoricus, is found at the northernmost sites Menez Gwen, Lucky Strike and Rainbow (Desbruyères et al., 2001). Transmission electron microscopy has demonstrated the presence of two distinct Gram-negative bacterial endosymbionts inside specialized gill epithelial cells (bacteriocytes). One of these symbionts has centrally stacked intracytoplasmic membranes characteristic for methane-oxidising gamma-proteobacteria (Fiala-Médioni et al., 2002). Analysis of 16S rRNA sequences followed by fluorescence in situ hybridization (FISH) evidenced that $B$. azoricus endosymbiotic 16S rRNA phylotypes cluster with natural symbiotic and cultured sulfide-oxidising (SOX) and methane-oxidising gamma-proteobacteria (Won et al., 2003; Duperron et al., 2006; Spiridonova et al., 2006). Enzymatic and physiological assays using gills of B. azoricus from the Lucky Strike and Menez Gwen vent sites revealed the presence of active enzymes of the metabolic cycles of inorganic $\mathrm{C}$ assimilation and sulfide oxidation and of the $\mathrm{C}_{1}$ carbon assimilation pathway (Fiala-Médioni et al., 2002). Furthermore, Riou et al. (2008) report active ${ }^{13} \mathrm{C}$ incorporation from bicarbonate

Published by Copernicus Publications on behalf of the European Geosciences Union. 
in the presence of sulfide as well as from methane within the gills of B. azoricus. This incorporation was followed by carbon transfer to the host's aposymbiotic muscle tissue.

In order to understand the modes of matter and energy transfer to the host, the phenotypes of B. azoricus symbionts' need to be characterized. Classification of phospholipid ester-linked fatty acids (PLFA) profiles has proven useful to clarify bacterial genus and species interrelationships established by DNA-based phylogeny (Bodelier et al., 2009). PLFA profiles thus allow to distinguish between different methane-oxidising bacteria (MOB) species as evidenced for example by the fact that methane-oxidising gammaproteobacteria (formerly named after "Type I MOB") mainly contain fatty acids with 14 and 16 carbon atoms, while methane-oxidising alpha-proteobacteria (formerly "Type II MOB") PLFA are mainly composed of 18 carbon atoms (Nichols et al., 1985). In addition, MOB bacteria possess fatty acids that are not found in any other known microorganism (methane-oxidising gamma-proteobacteria: 16:1(n-8) and 16:1(n-5)t; alpha-proteobacteria: $18: 1(n-8))$ and these compounds therefore represent valuable biomarkers (e.g. Nichols et al., 1985).

The main difficulty consists in the impossibility to grow B. azoricus' symbionts in pure cultures. Tracer experiments represent powerful tools enabling the detection of the bacterial fatty acid signal inside the host. However, in a tissue total lipid extract, the symbionts' fatty acid molecules are "diluted" by the fatty acids of the eukaryotic cells since the bacterial symbionts are hosted inside mussel cells. Unlike plant and animal cells, bacteria do not contain acyl lipid stores (lipids containing O- or $\mathrm{N}$-ester or ether linked fatty acids), and it is believed that their acyl lipids are confined to membranes. Phospholipids represent 90 to $98 \%$ of bacterial lipids (King et al., 1977; White et al., 1979) and around $50 \%$ of eukaryotic lipids (Vestal and White, 1989). Studying PLFA thus somehow "concentrates" the signal of the bacteria, and is more adapted than a total fatty acid study in the perspective of identifying the fatty acids that are produced by the symbionts from the assimilation of $\mathrm{CH}_{4}$ and $\mathrm{CO}_{2}$ (in the presence of sulfide).

In the present study, we thus investigated the incorporation of ${ }^{13} \mathrm{C}$-labeled $\mathrm{HCO}_{3}^{-}$(in the presence of $\mathrm{H}_{2} \mathrm{~S}$ ) or $\mathrm{CH}_{4}$ into gill-extracted PLFA from B. azoricus in order to assess the metabolic activity of the endosymbionts. This enabled us to establish specific fatty acid (FA) patterns which provide insights into the symbiont phenotypes. On the contrary, a technique with a high yield of tissue total fatty acid (tFA) recovery was preferred to retain most of the information relative to both the symbionts and the host's fatty acids when analysing the assimilation of ${ }^{13} \mathrm{C}$-labeled amino acids (dissolved into seawater) into B. azoricus gill fatty acids. This last experiment was indeed designed to observe (i) the potential for heterotrophic growth by the symbionts, and/or (ii) the occurrence of lipogenesis from the assimilation of amino acids by the Mytilid cell machinery (which could also use free amino acids as osmotic regulators of the cells, metabolic fuel, protein synthesis or in the glucogenesis). Close examination of the labeled FA patterns helped interpreting physiological processes occurring in B. azoricus.

\section{Material and methods}

\subsection{Sampling and aquarium experiments}

During the MOMARETO cruise ( $R / V$ Pourquoi Pas?) in August 2006, a cage was deployed at the Menez Gwen site $\left(37^{\circ} 51^{\prime} \mathrm{N}-32^{\circ} 31^{\prime} \mathrm{W}, 817 \mathrm{~m}\right)$ and loaded with around 400 mussels. The cage was retrieved in May 2007 by the Portuguese vessel $R / V$ Arquipélago. Bathymodiolus azoricus specimens were transferred to cooled seawater $\left(9^{\circ} \mathrm{C}\right)$ for a $14 \mathrm{~h}$ transit to Horta, Faial Island (Azores). Their valves were scrubbed clean of visible material, rinsed in chilled seawater and transferred to the Azorean land-based hydrothermal vent laboratory, LabHorta (Colaço and Santos, 2003). Before the start of the experiments, mussels were kept for 38 days in aerated seawater amended with methane and hydrogen sulfide, as described in Riou et al. (2008).

\subsection{Mussels incubation with ${ }^{13} \mathrm{C}$-enriched substrates}

All stable isotope enriched chemicals were purchased from Campro Scientific (The Netherlands). For the experiments, 42 adult mussels (55.6 to $72.4 \mathrm{~mm}$ Shell Length) were dispatched into 4 separate refrigerated 4-L aquaria with aerated $0.2 \mu \mathrm{m}$-filtered natural seawater replaced every second day and monitored daily for temperature $\left(7.8-9.8^{\circ} \mathrm{C}\right), \mathrm{pH}(7.1-$ 8.6) and $\mathrm{O}_{2}$ saturation (median: $45 \%$ ). The available quantity of labelled methane $\left(25 \%{ }^{13} \mathrm{C}\right)$ allowed running the tracer experiment with ${ }^{13} \mathrm{CH}_{4}$ for a period of 15 days with a final dissolved concentration ranging between $14-200 \mu \mathrm{mol} \mathrm{L}^{-1}$ (Riou et al., 2008). The control experiment (with filtered seawater only) and the experiments with $\mathrm{NaH}^{13} \mathrm{CO}_{3}(99 \%$ added to the filtered seawater to obtain a concentration of $\left.2.85 \mathrm{mmol} \mathrm{L}^{-1}, 16.3 \%{ }^{13} \mathrm{C}\right)+\mathrm{H}_{2} \mathrm{~S}\left(0-32 \mu \mathrm{mol} \mathrm{L}^{-1}\right.$, Riou et al., 2008) or with $9 \mathrm{mg} \mathrm{L}^{-1}$ of a ${ }^{13} \mathrm{C}$-labeled amino acid mixture $\left(98 \%{ }^{13} \mathrm{C}\right.$, Riou et al., 2010) were continued over a period of 20 days. The amino acid mixture consisted of Gly $20-25 \%$, Ala $15-20 \%$, Tyr $10-15 \%$, Leu $5-10 \%$, Lys $5-10 \%$, Ser $5-10 \%$, Thr $2-5 \%$, Phe $1-5 \%$, Pro $1-5 \%$, Val $1-5 \%$, Met $<3 \%$, Trp $<1 \%$, Ile $<1 \%$, His $<1 \%$.

Three mussels from each experiment were selected for fatty acid analysis, and dissected into gill, mantle, muscle, and remaining tissues. Mussel tissues were immediately stored at $-20^{\circ} \mathrm{C}$ till they were freeze-dried, a few days after dissection.

\subsection{PLFA and tFA preparation}

Prior to use, all glassware was precombusted $4 \mathrm{~h}$ at $450{ }^{\circ} \mathrm{C}$. Lipids were extracted from approximately $100 \mathrm{mg}$ dry tissue 
(ground to a fine powder right before extraction, using a mortar and pestle) by a modified Bligh and Dyer protocol (Boschker et al., 1998), whereby water in the first extraction step was replaced by Sörens phosphate buffer $\mathrm{pH} 7.4$ (White et al., 1979). Lipid extracts were fractionated on silicic acid columns into different polarity classes by sequential elution with chloroform, acetone and finally methanol. The phospholipids collected in the methanol fraction were derivatized using mild-alkaline methanolysis (using a methanolic $\mathrm{KOH}$ solution) to yield fatty acid methyl esters (hereafter refered to as PLFA since they were derived from the phospholipid fraction).

Total fatty acid methyl esters (tFA) were obtained from $25 \mathrm{mg}$ tissue powder by direct acid methanolysis catalysed for $2 \mathrm{~h}$ at $90^{\circ} \mathrm{C}$ (modified from Lewis et al., 2000) in $3 \mathrm{~mL}$ of a fresh solution of methanol/hydrochloric acid $37 \% / \mathrm{chlo-}$ roform (10:1:1 volume). After cooling down to room temperature chloroform $(1 \mathrm{~mL})$ and water $(1 \mathrm{~mL})$ were added to the samples which were then well mixed before the biphasic system was allowed to separate. The chloroform fraction was transferred to a fresh tube and the upper phase was reextracted with fresh chloroform $(1 \mathrm{~mL})$. Chloroform extracts were pooled, cleaned with $2 \mathrm{~mL}$ water, dried under a mild nitrogen flow and the tFA were re-suspended in $300 \mu \mathrm{L}$ hexane.

\subsection{FAME fractionation on $\mathrm{Ag}^{+}$-SPE cartridges}

PLFA and tFA fractions were resolved further as a function of degree of unsaturation (saturated, trans-mono-unsaturated, cis-mono-unsaturated, di-unsaturated and poly-unsaturated), using silver ion solid phase extraction columns $\left(\mathrm{Ag}^{+}\right.$SPE cartridges, Supelco Inc., Bellafonte, PA). The protocol used by Kramer et al. (2008) was modified to recover poly-unsaturated fatty acids (PUFA) using $5 \mathrm{~mL}$ acetone/acetonitrile (60:40 volume), directly after eluting the diunsaturated fraction.

\subsection{FAME ${ }^{13} \mathrm{C}$ content analyses and identification}

The isotopic composition of individual FAME was analysed by gas chromatography-combustion-isotope ratio mass spectrometry (GC-c-IRMS) using an HP6890 coupled to a Thermo Finnigan delta+XL via a GC/C III interface. The FAME mix and $\mathrm{Ag}^{+}$-SPE fractions were resolved on a fused-silica capillary column $(100 \mathrm{~m} \times 0.25 \mathrm{~mm})$ coated with $0.20 \mu \mathrm{m}$ CP-Sil 88 (100\% cyanopropyl polysiloxane, Varian BV, The Netherlands) after injection in splitless mode at $270^{\circ} \mathrm{C}$. Helium was used as a carrier gas at a flow rate of $1 \mathrm{~mL} \mathrm{~min}^{-1}$ and the following temperature program was applied: $4 \mathrm{~min}$ at $45^{\circ} \mathrm{C}$; an increase at $10^{\circ} \mathrm{C} \min ^{-1}$ to $135^{\circ} \mathrm{C}$ and a plateau of $90 \mathrm{~min}$; an increase at $5^{\circ} \mathrm{C} \mathrm{min}-1$ to $170^{\circ} \mathrm{C}$ and a plateau of $25 \mathrm{~min}$; an increase at $10^{\circ} \mathrm{C} \mathrm{min}^{-1}$ to $195^{\circ} \mathrm{C}$ and a plateau of $15 \mathrm{~min}$; an increase at $10^{\circ} \mathrm{C} \mathrm{min}{ }^{-1}$ to $235^{\circ} \mathrm{C}$ and a plateau of $5 \mathrm{~min}$. A careful selection of the type of chromatographic column and the optimization of the
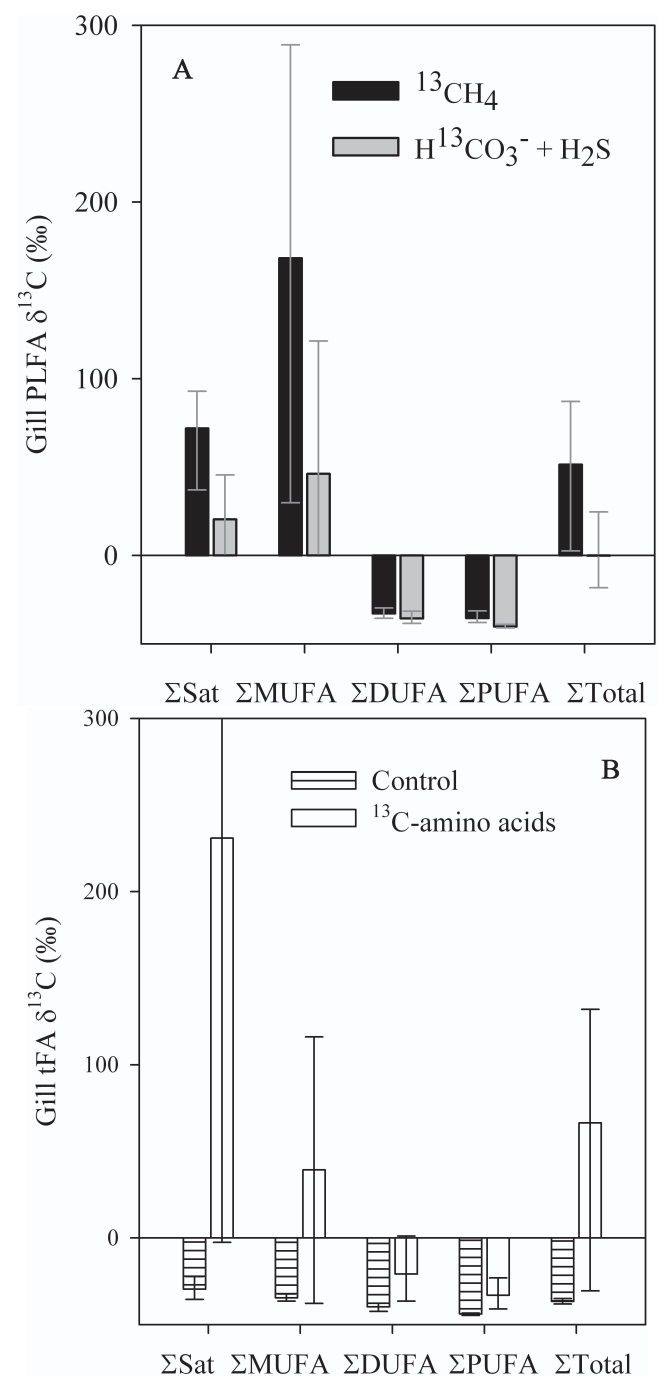

Fig. 1. Bathymodiolus azoricus $(n=3$ specimens, mean \pm min$\max )$ gill FAME carbon isotopic signatures. The $\delta^{13} \mathrm{C}$ signatures were corrected for the methyle group added during the transesterification using formula (1), and weighed averages were obtained using formula (2) (A) Gill PLFA after 15 days with $28 \mu \mathrm{M}$ $25 \%{ }^{13} \mathrm{CH}_{4}$ (black bars) or 20 days with $6 \mu \mathrm{M} \mathrm{H}_{2} \mathrm{~S}+16 \%$ $\mathrm{H}^{13} \mathrm{CO}_{3}^{-}$(grey bars). (B) Gill total fatty acids (tFA) after 20 days in control conditions (striped bars) or 20 days with $300 \mu \mathrm{M}$ dissolved $98 \%{ }^{13} \mathrm{C}$-amino acids (white bars). Sat: saturated, MUFA: mono-unsaturated, DUFA: di-unsaturated, PUFA: poly-unsaturated chains.

temperature program (enabling the detection of FAME 10:0 to 24:0) ensured baseline resolution of the IRMS $m / z, 44$ trace for the majority of the components (including 16:1 and 18:1 positional isomers) and enabled an accurate identification of labeled PLFA. The $\delta^{13} \mathrm{C}$ ratios of each FAME was corrected for the addition of one methanol carbon per molecule to obtain the isotopic signature of the fatty acid as in Abrajano et al. (1994) using the mass balance equation taking a measured $\delta^{13} \mathrm{C}_{\mathrm{CH}_{3} \mathrm{OH}}$ value of $-40.3 \%$ : 
$\delta^{13} C_{\mathrm{FAME}}=[x] \delta^{13} C_{\mathrm{FA}}+[1-x] \delta^{13} C_{\mathrm{CH}_{3} \mathrm{OH}}$

Where $x$ is the fractional carbon contribution of the free fatty acid to the methyl ester (e.g.: 18/19 for FA 18:1(n-7)).

The weighed $\delta^{13} \mathrm{C}$ signature of fatty acid methyl esters, grouped according to their degree of unsaturation (Fig. 1), was obtained using the following formula (with monounsaturated fatty acids -MUFA- taken as an example of fatty acid class):

$$
\begin{aligned}
& \delta^{13} C \mathrm{MUFA}=\left(\% \mathrm{MUFA}_{1}{ }^{*} \delta^{13} \mathrm{CMUFA}_{1}+\ldots+\right. \\
& \left.\% \mathrm{MUFA}_{z}{ }^{*} \delta{ }^{13} \mathrm{MUFA}_{z}\right) /\left(\Sigma \% \mathrm{MUFA}_{1} \text { to } z\right)
\end{aligned}
$$

where $\% \mathrm{MUFA}_{x}$ is the area obtained from MUFA $x$ on the chromatogram relative to the sum of the areas obtained from all fatty acids, and $\delta^{13} \mathrm{CMUFA}_{x}$ is the carbon isotopic signature of MUFA .

For each PLFA, the incorporation of ${ }^{13} \mathrm{C}$ (I, expressed as micrograms of ${ }^{13} \mathrm{C}$ per gram of total PLFA) was calculated as in Knief et al. (2003):

$\mathrm{I}=\left(F_{l}-F_{u}\right) \cdot\left(\mathrm{A}_{x}\right)$

where $A_{x}$ is the peak area of PLFA ${ }_{x}$ divided by the sum of the peak areas of all of the PLFA. $F$ is the fraction of ${ }^{13} \mathrm{C}$ in $\mathrm{PLFA}_{x}$ of samples incubated with ${ }^{13} \mathrm{C}\left(F_{l}\right)$ or in $\mathrm{tFA}_{x}$ of control unlabelled samples $\left(F_{u}\right): F={ }^{13} \mathrm{C} /\left({ }^{13} \mathrm{C}+{ }^{12} \mathrm{C}\right)=R /(R+$ $1)$. The carbon isotope ratio $(R)$ was derived from the measured $\delta^{13} \mathrm{C}$ values as follows: $R=\left(\delta^{13} \mathrm{C} / 1000-1\right) \cdot R_{\mathrm{VPDB}}$, with $R_{\mathrm{VPDB}}=0.0112372$.

FAME identification was achieved by GC-mass spectrometry (GC-MS) using a Thermo Finnigan TRACE GC-MS system, applying the same GC conditions as described for the GC-IRMS analyses. The mass spectrometer was operated under mild conditions of electron impact ionization $\left(\mathrm{EI}^{+} ; 40 \mathrm{eV}\right)$ and recorded the mass spectra in the scan mode $(\mathrm{m} / \mathrm{z}=50-400)$. Aliquots of the PLFA or tFA mixture and of the MUFA, DUFA and PUFA fractions were derivatised further by a one step reaction into dimethyloxazolines (DMOX) to locate the unsaturations by GC-MS (Fay and Richly, 1991). We used a temperature gradient similar to the one used for FAME analyses, but since DMOX derivatives are less volatile (see also Precht and Molkentin, 2000) we increased the temperature of the isotherm plateaus at $135^{\circ} \mathrm{C}, 170^{\circ} \mathrm{C}$ and $195^{\circ} \mathrm{C}$ for the temperature program described above, by $10^{\circ} \mathrm{C}$ to $145^{\circ} \mathrm{C}, 180^{\circ} \mathrm{C}$ and $205^{\circ} \mathrm{C}$, respectively. The International Union of Pure and Applied Chemistry PLFA nomenclature used here is described by Guckert et al. (1985): the $(n-)$ notation indicates the position of the carbon-carbon double bond in the FA aliphatic chain starting from the methyl end carbon. The $\Delta$ notation, giving the location of FA unsaturation from the carbon at the carboxyl end, is only used in the next paragraphs to discuss fatty acid synthesis.

\section{Results and discussion}

\subsection{Methane- and sulfide-oxidizing bacteria PLFA fingerprint}

Phenotypic characterization is important for accurate taxonomic description of the endosymbionts (Bowman et al., 1993) and interpretation of the compound specific natural stable isotopic signatures. Pond et al. (1998) observed that the 14:0, 18:0,18:1(n-7), 20:1(n-7), 18:3(n-7), and 20:3(n-7) compounds in the total lipid extract from Bathymodiolus azoricus gills were isotopically light and concluded these compounds had been produced by the sulfideoxidising endosymbiotic bacteria (SOX). Our experimental results contrast with these conclusions and indicate that (i) 14:0, 18:0, 18:1(n-7) and 20:1(n-7) compounds also incorporate $\mathrm{C}$ from ${ }^{13} \mathrm{CH}_{4}$ and (ii) 18:0, 20:1 $(n-7), 18: 3(n-$ 7) and 20:3(n-7) compounds do not incorporate significant amounts of ${ }^{13} \mathrm{C}$ from $\mathrm{H}^{13} \mathrm{CO}_{3}^{-}$in the presence of $\mathrm{H}_{2} \mathrm{~S}$.

Our study shows that mussels kept in the presence of ${ }^{13} \mathrm{CH}_{4}$ or $\mathrm{H}^{13} \mathrm{CO}_{3}^{-}+\mathrm{H}_{2} \mathrm{~S}$ incorporate ${ }^{13} \mathrm{C}$ mainly in saturated and mono-unsaturated PLFA (Sat and MUFA, respectively, Fig. 1a). For instance, the weighed average $\delta^{13} \mathrm{C}$ signature of $\Sigma$ MUFA from the gill PLFA fraction of mussels incubated with ${ }^{13} \mathrm{CH}_{4}$ varied between +27 and $+249 \%$ o (Fig. 1a). From the ${ }^{13} \mathrm{CH}_{4}$ and $\mathrm{H}^{13} \mathrm{CO}_{3}^{-}+\mathrm{H}_{2} \mathrm{~S}$ experiments, three patterns can be distinguished (Fig. 2): (i) PLFA enriched in ${ }^{13} \mathrm{C}$ from both substrates $\left(\mathrm{CH}_{4}\right.$ and $\left.\mathrm{HCO}_{3}^{-}+\mathrm{H}_{2} \mathrm{~S}\right)$, i.e. $14: 0 ; 15: 0 ; 16: 0 ; 16: 1(n-7) c+t ; 18: 1(n-13) c+t$ and $(n-7) c+t ; 20: 1(n-7) ; 20: 2(n-9,15) ; 18: 3(n-7)$ and $(n-5,10,13)$; (ii) PLFA enriched in ${ }^{13} \mathrm{C}$ only after exposure to ${ }^{13} \mathrm{C}_{-} \mathrm{CH}_{4}$, i.e., $17: 0 ; 18: 0 ; 16: 1(n-9) ; 16: 1(n-8)$ and $(n-6) ; 18: 1(n-8)$; and 18:2(n-7) (note that fatty acid $18: 1(n-9)$ was enriched in only one of the replicate specimens) and (iii) PLFA enriched in ${ }^{13} \mathrm{C}$ only after exposure to $\mathrm{H}^{13} \mathrm{CO}_{3}^{-}$and $\mathrm{H}_{2} \mathrm{~S}$ : i.e., 12:0. Exposure to $\mathrm{H}^{13} \mathrm{CO}_{3}^{-}$and $\mathrm{H}_{2} \mathrm{~S}$ also resulted in 17:1(n-8), 20:2(n-9,15) and 20:5(n-3) enrichement in two, and 20:2(n-7,11) and 18:3(n-6) in only one out of the three specimens analyzed.

Phylogenetic analyses on sequences of the genes encoding the 16S rRNA subunit and the particulate methane monooxygenase ( $p m o A$ gene) revealed that the B. azoricus methaneoxidising endosymbiont is a gamma-proteobacterium related to free living $\mathrm{MOB}$ and to $\mathrm{MOB}$ symbionts from other Bathymodiolids (Duperron et al., 2006; Nakagawa and Takai, 2008; Spiridonova et al., 2006). Although Colaço et al. (2007) did not identify any MOB PLFA biomarkers in wild B. azoricus specimens from the Menez Gwen site they did reveal the presence of large amounts of i19:0, 18:1(n-13) and 18:1(n-9), which were attributed to the endosymbionts. Our tracer experiment with ${ }^{13} \mathrm{CH}_{4}$ revealed that $18: 1(n-13)$ was indeed slightly labeled but this was not the case for 18:1(n-9) (not enriched in the presence of $\mathrm{H}^{13} \mathrm{CO}_{3}^{-}+\mathrm{H}_{2} \mathrm{~S}$ either) or for i19:0 which was not detected in our specimens. 


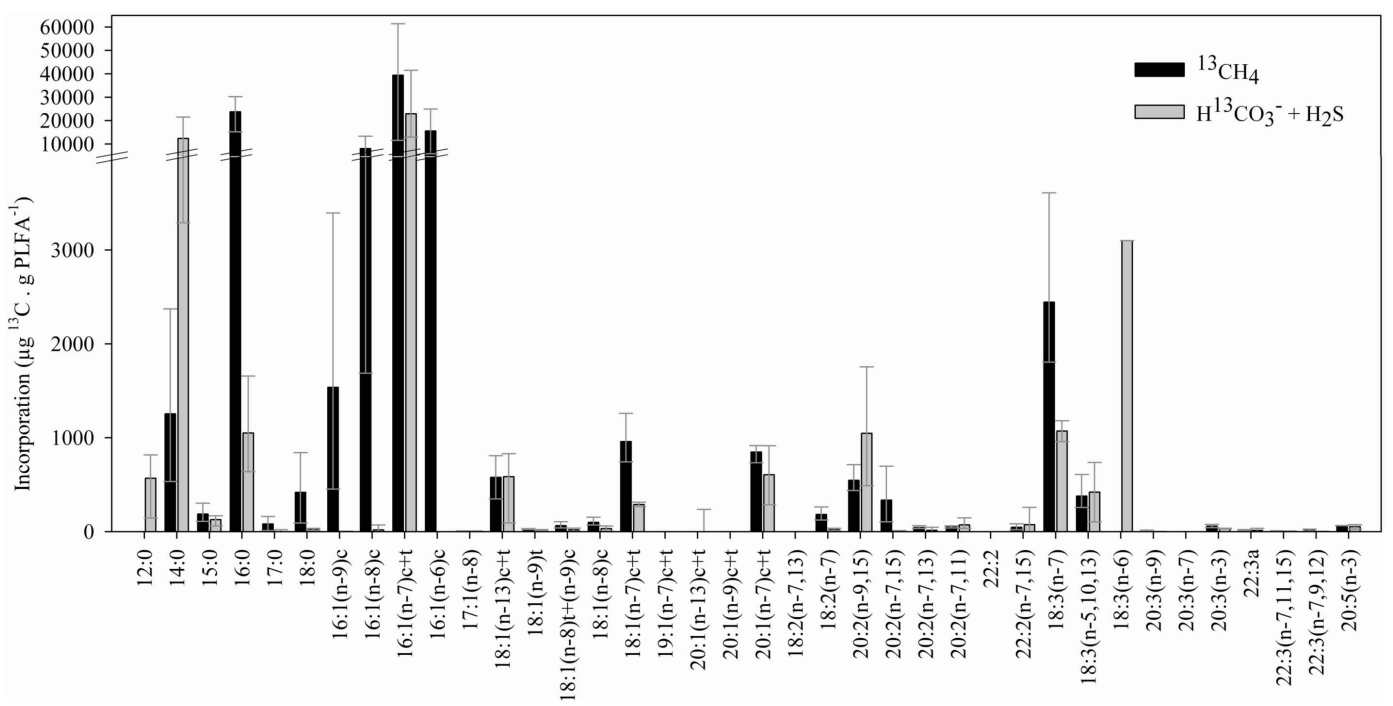

Fig. 2. Bathymodiolus azoricus gill tissue PLFA $(n=3$, average \pm min-max $){ }^{13} \mathrm{C}$ incorporation per total PLFA content (as calculated using Eq. 3) after a 15 day supply with ${ }^{13} \mathrm{CH}_{4}$ (black bars), or a 20 day supply with $\mathrm{H}^{13} \mathrm{CO}_{3}^{-}$in the presence of $\mathrm{H}_{2} \mathrm{~S}$ (grey bars).

As mentioned above, we found that ${ }^{13} \mathrm{CH}_{4}$ incorporated in B. azoricus gill tissue ended up in 14:0, 15:0, 16:0 as well as in cis and trans 16:1(n-9,8,7 and 6) PLFA (Fig. 2). 16:1(n-9) (one of the least abundant 16:1 isomers) also became labeled, although this compound has not been observed previously in PLFA profiles of isolated methanotrophic strains (Bodelier et al., 2009). Overall, Methylohalobium crimeensis $1 K i$ has a PLFA profile which overlaps by $98.1 \%$ with the fatty acid profile identified by stable isotope labeling with ${ }^{13} \mathrm{CH}_{4}$ of the B. azoricus MOB symbiont, followed by Methylosphaera hansonii ACAM 549 (97.0\%, Table 1, Bodelier et al., 2009), Methylocaldum sp. O-12 (95.8\%) and Methylocaldum sp. H-11 (93.0\%). This result is consistent with the study of Pimenov et al. (2002) who could amplify total DNA isolated from B. azoricus gill tissue exclusively with $16 \mathrm{~S}$ rRNA primers targeting the genera Methylobacter and Methylosphaera.

Phylogenetically the $B$. azoricus SOX endosymbiont stands far from any known cultured SOX bacteria. The closest strains such as the obligate chemolithoautotrophic thiodenitrifying gamma-proteobacteria Thiohalomonas nitratireducens (Sorokin et al., 2007) only reach around 88\% 16S rRNA sequence homology (S. Duperron, personal communication, 2009). Furthermore, the PLFA labeled in our experiments represented only $69 \%$ of the fatty acid (FA) extracted from $T$. nitratireducens. It is thus difficult to relate the phenotype of B. azoricus SOX symbiont to any free-living bacteria.

Conway and MacDowell Capuzzo (1991) suggested that all SOX bacteria desaturate their FA via the anaerobic pathway. The anaerobic desaturation pathway produces long chain MUFA by the elongation of medium chain length cis3-unsaturated intermediates, with 18:1(n-7) as the major end-product and 16:1(n-7) as a secondary product. The
$\mathrm{O}_{2}$-dependent MUFA synthesis pathway is known to produce a large variety of fatty acids (FA) with a double bond insertion occurring mainly in the $\Delta 9$ position (Conway and MacDowell Capuzzo, 1991). Note that the delta $(\Delta)$ nomenclature which imposes carbon atoms numbering to start from the carboxylic acid end of the acyl chain, is used for describing biochemical reactions. Our results show that 18:1(n-7) and 16:1(n-7), which are the main products of the anaerobic desaturation pathway, were significantly more labeled $(-19.8$ and $+182.2 \%$, respectively) than the main product of aerobic desaturation, $\Delta 9$ MUFA 18:1(n-9) $(-29.6 \%$, Fig. 2). However, the latter fatty acid was less abundant, and therefore incorporation of similar levels of label in the 3 fatty acids could have resulted in a higher $\delta^{13} \mathrm{C}$ signature in PLFA 18:1(n-9). The fact that MUFA 16:1(n-7), which was approximately 3 and 9 fold more abundant than 18:1 $(n-7)$ and 18:1(n-9), respectively (Fig. 4), was the most labeled compound together with saturated PLFA (12:0, 14:0 and 15:0; see Fig. 2), supports the contention of Conway and MacDowell Capuzzo that B. azoricus SOX symbiont desaturates its FA via the anaerobic pathway.

\subsection{Amino acid assimilation in tFA}

Wright (1982) reports that Mytilus and Modiolus mussels take up free amino acids dissolved in seawater. Once inside the cell, free amino acids can be incorporated unchanged into proteins (Eccleston and Kelly, 1972) or used for the synthesis of other macromolecules. Excess amino acids (not being incorporated into proteins) cannot be stored in the cells and are generally used as metabolic fuel for the production of FA, ketone bodies or glucose (Berg et al., 2002). The ketogenic amino acids leucine, lysine, isoleucine, phenylalanine, 
Table 1. PLFA displaying significant enrichement after the tracer experiments with $\mathrm{H}_{2} \mathrm{~S}+{ }^{13} \mathrm{CO}_{2}(\mathrm{SOX})$ or with ${ }^{13} \mathrm{CH} 4(\mathrm{MOB}) . \mathrm{X}={ }^{13} \mathrm{C}$ labeled. \% PLFA = proportion of the PLFA content in cultured strains of Methylosphaera hansonii and Thiohalomonas nitratireducens.

\begin{tabular}{|c|c|c|c|c|}
\hline & MOB & $\begin{array}{l}\text { M. hansonii (\% PLFA) } \\
\text { Bodelier et al., } 2009\end{array}$ & SOX & $\begin{array}{l}\text { T. nitratireducens (\% PLFA) } \\
\text { Sorokin et al., } 2007\end{array}$ \\
\hline $12: 0$ & & & $X$ & 3.9 \\
\hline 14:0 & $X$ & 2.5 & $\mathrm{X}$ & 0.5 \\
\hline $15: 0$ & $X$ & 1.5 & $X$ & 0.6 \\
\hline $16: 0$ & $X$ & 14.5 & $X$ & 25.4 \\
\hline $18: 0$ & $X$ & 0 & $X$ & 0.5 \\
\hline $16: 1(n-6)$ & $X$ & 17.5 & & \\
\hline $16: 1(n-7) c+t$ & $\mathrm{X}$ & 20 & $\mathrm{X}$ & 27.3 \\
\hline $16: 1(n-8)$ & $X$ & 39 & & \\
\hline $16: 1(n-9)$ & $X$ & 0 & & \\
\hline $17: 1(n-8)$ & & & $X$ & 0.9 \\
\hline $18: 1(n-7) c+t$ & $X$ & 1.5 & $\mathrm{X}$ & 11.8 \\
\hline $18: 1(n-8)$ & $\mathrm{X}$ & 0 & & \\
\hline $18: 1(n-9)$ & $X$ & 0.5 & $X$ & 5.1 \\
\hline $18: 1(n-13) c+t$ & $X$ & 0 & & \\
\hline $20: 1(n-7)$ & $X$ & 0 & & \\
\hline $18: 2(n-7)$ & $\mathrm{X}$ & 0 & & \\
\hline
\end{tabular}

tryptophan and tyrosine (accounting for 41 to $72 \%$ of the ${ }^{13} \mathrm{C}$-amino acid mix used in our tracer experiment, see Riou et al., 2010) can be degraded into acetoacetyl CoenzymeA or acetyl-CoA, which constitutes the basis for de novo FA biosynthesis (e.g., Payne et al., 2001). Alanine, serine and cysteine can be converted to pyruvate which can further turn into acetyl CoA. Tracing the incorporation of amino acid ${ }^{13} \mathrm{C}$ into FA biomarkers may thus provide evidence for an osmotrophic activity (feeding on dissolved organics) by $B$. azoricus itself and/or by its endosymbionts. While from the present study (and Riou et al., 2008) it is now clear that $B$. azoricus' symbionts assimilate $\mathrm{CH}_{4}$ or $\mathrm{HCO}_{3}^{-}$in the presence of $\mathrm{H}_{2} \mathrm{~S}$, their potential for osmotrophy has never been studied. The gill tissue showed the most rapid evidence of ${ }^{13} \mathrm{C}$ incorporation from labeled amino acids (Riou et al., 2010). Since the symbionts are located in the gill tissue, they might thus have increased access to such organic food source. However, mussel epithelial cells are the first to access this potential carbon and nitrogen source, since amino acids first enter the gill epithelial cells before they can reach MOB and SOX bacterial cytoplasms.

The experiment with ${ }^{13} \mathrm{C}$ labeled amino acids resulted in significant enrichment of the majority of the total fatty acids (tFA, Fig. 3). Out of the 38 gill tissue tFA only 14 did not show significant enrichment. Among these were the MUFA $16: 1(n-9)$ and $18: 1(n-8)(1.6 \%$ of the tFA area, Fig. 4), 19:1(n-7) (0.5\%), and 20:1(n-13) (4.4\%); the non-methylene interrupted di-unsaturated (NMID) fatty acids $18: 2(n-7,13)(0.4 \%), 20: 2(n-7,15)(6.2 \%)$; and the PUFA 18:3(n-5,10,13) (5.3\%), 20:3(n-7) (2.3\%) and 22:3 isomers $(1.5 \%)$. The fatty acid showing most ${ }^{13} \mathrm{C}$ incorpo- ration from the amino acids was 12:0 (representing $2.1 \%$ of tFA, Fig. 4), followed by $16: 1(n-7)(16.0 \%), 18: 1(n-7)$ $(2.7 \%)$ and $16: 0(19.1 \%$ of tFA).

Mollusc lipids contain non-methylene interrupted diunsaturated (NMID) FA having unusual unsaturation features, since they possess double bonds with more than one methylene group between ethylenic bonds (reviewed in Barnathan, 2009). We observed that the incorporation of ${ }^{13} \mathrm{C}$ from labeled amino acids in gill tissue di-unsaturated tFA ("DUFA" with these being mainly composed of NMID FA; $\delta^{13} \mathrm{C}_{\text {DUFA }}=-20.9 \%$ ) was significantly higher than the ${ }^{13} \mathrm{C}$ incorporation from $\mathrm{CH}_{4}$ or $\mathrm{HCO}_{3}^{-}+\mathrm{H}_{2} \mathrm{~S}(-32.8$ and $-35.6 \%$, respectively, Fig. 1a, b). In particular, the NMID 22:2(n-7,15) became labeled only when supplying $B$. azoricus with ${ }^{13} \mathrm{C}$-amino acids (Fig. 3 ). In bivalves, NMID $22: 2(n-9,15)$ and $22: 2(n-7,15)$ (usually the most abundant in marine invertebrates, see e.g., Dunstan et al., 1993; Kawashima et al., 2003) are synthesized de novo by elongation and $\Delta 5$ desaturation of $18: 1(n-9)$ and 16:1 $(n-7)$ (Zhukova, 1986) and subsequent elongation of 20:2(n-9,15) and 20:2 $(n-7,15)$ into the $22: 2(n-9,15)$ and $22: 2(n-7,15)$ acids. The incorporation of ${ }^{13} \mathrm{C}$ label in $22: 2(n-7,15)$ therefore indicates that the mollusc host cells have assimilated the amino acids directly in their fatty acids (as opposed to $\mathrm{CH}_{4}$ and $\mathrm{HCO}_{3}^{-}$which are being assimilated by the symbionts). Further evidence for this comes from the observation that MUFA 18:1(n-9) as well as 20:1(n-9) were more enriched in gills of specimens incubated with ${ }^{13} \mathrm{C}$-amino acids (Fig. 3) than in mussels kept in the presence of ${ }^{13} \mathrm{CH}_{4}$ or ${ }^{13} \mathrm{CO}_{2}+\mathrm{H}_{2} \mathrm{~S}$ (Fig. 2), even though $\sum$ MUFA in the amino acid experiment was less labeled $\left(+39 \%\right.$, Fig. 1b) than $\sum$ MUFA for 


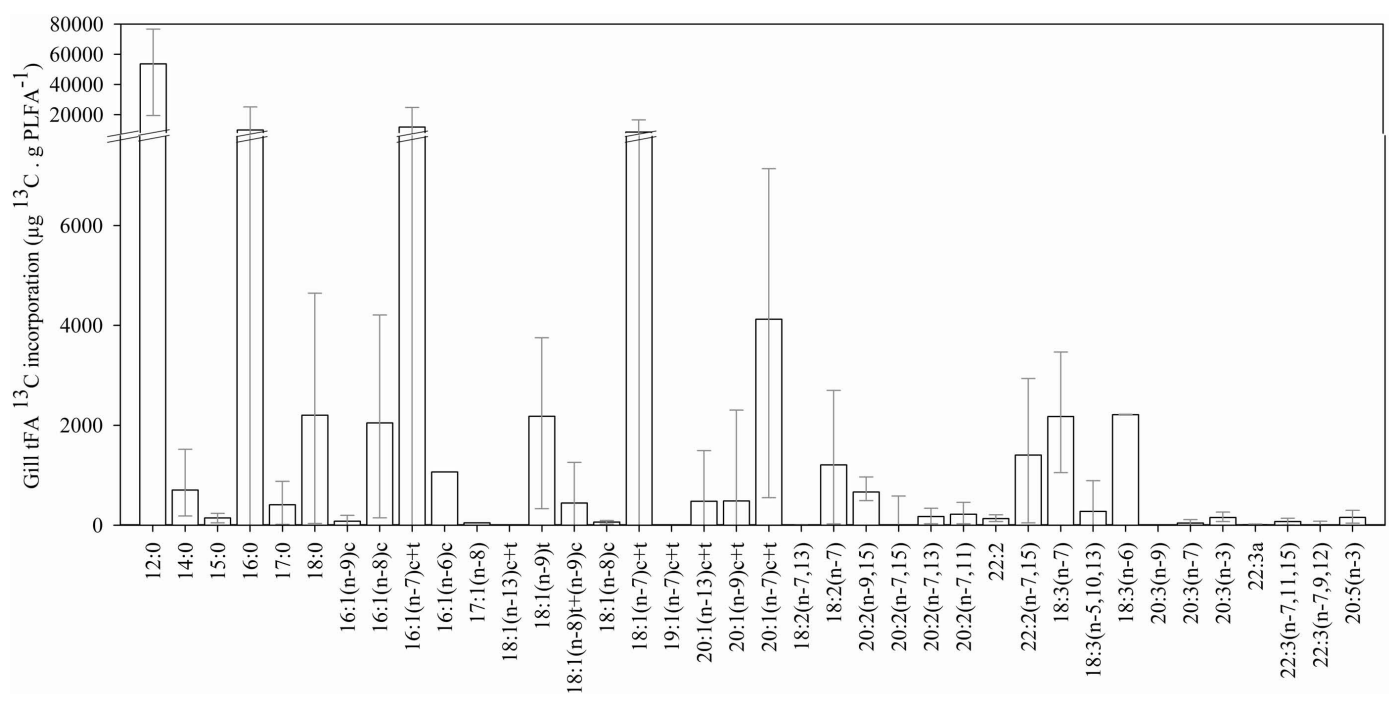

Fig. 3. Bathymodiolus azoricus gill tissue tFA $(n=3$, average \pm min-max $){ }^{13} \mathrm{C}$ incorporation per total PLFA content after a 20 day supply of dissolved ${ }^{13} \mathrm{C}$-amino acids.

the ${ }^{13} \mathrm{CH}_{4}$ or ${ }^{13} \mathrm{CO}_{2}+\mathrm{H}_{2} \mathrm{~S}$ experiments $(+168$ and $+46 \%$, respectively, Fig. 1a). In animal cells, mono-unsaturation of fatty acids is catalyzed by a $\Delta 9$ desaturase which has a maximum affinity for FA 18:0 and yields $18: 1 \Delta 9(18: 1(n-9)$; Cook, 1996). Since filter-feeding molluscs elongate de novo produced 18:1(n-9) to 20:1(n-9) (Zhukova, 1986), the observed preferential incorporation of ${ }^{13} \mathrm{C}$ from amino acids in 18:1(n-9) as well as 20:1(n-9), indeed points to direct assimilation of amino acids by the Mytilid cell machinery.

As can be noticed from Fig. 3, FA belonging to the $(n-7)$ series were particularly enriched, with $16: 1(n-7)$ showing the highest ${ }^{13} \mathrm{C}$ incorporation within this series, followed by $18: 1(n-7), 20: 1(n-7), 18: 3(n-7)$ and 18:2(n-7). One of the pathways of $18: 1(n-7)$ synthesis is the anaerobic pathway of desaturation, and Tunlid and White (1992) proposed $18: 1(n-7)$ to be a general indicator of the presence of bacteria. However, the high enrichment from ${ }^{13} \mathrm{C}$-amino acids observed for 18:1(n-7), 18:2(n-7), 18:3(n-7) and $20: 1(n-7)$ could also indicate preferrential use of the labeled acetyl coA resulting from amino acid breakdown to elongate 16:1(n-7), which is one of the most abundant FA (around 10\%, Fig. 4) in gill tissue. Indeed, had the ${ }^{13} \mathrm{C}$ amino acids been assimilated by the SOX endosymbionts first, 16:1 $(n-7)$ would have ended up being much more labeled than 18:1(n-7), as was observed in the $\mathrm{H}^{13} \mathrm{CO}_{3}^{-}+$ $\mathrm{H}_{2} \mathrm{~S}$ experiment. Although it is true that $16: 1(n-7)$ and 18:1(n-7) are the most abundant FA in SOX bacteria (McCaffrey et al., 1989) and that 18:1(n-7) dominates the PLFA profiles of facultative methanotrophic alpha-proteobacteria Methylocella species (Dedysh et al., 2005), these particular FA are also biosynthesized by eukaryotic organisms. The elongation of $16: 1(n-7)$ to form $18: 1(n-7)$ by the incorporation of enriched acetyl coA resulting from amino acid degradation might thus be performed by the mussel itself.
The incorporation of amino acid ${ }^{13} \mathrm{C}$ into SOX and MOB FA biomarkers $(12: 0$, and $16: 1(n-8)$ and $(n-6)$, respectively) might indicate that the symbionts could also be assimilating the amino acids directly. Bacteria indeed possess effective metabolic mechanisms to survive long periods of low food supply and to react rapidly to available suitable nutrients (including low concentrations of dissolved organic matter; Sepers, 1977). The SOX Beggiatoa bacteria, for instance, can grow facultatively or mixotrophically on inorganic and soluble organic compounds (Zhang et al., 2005). However, in general, organic compounds do not stimulate the growth of specialist phototrophs, lithotrophs, or methylotrophs. Although some of the isolated bacteria strains using methane and other $\mathrm{C}_{l}$ compounds also grow on sugars and acids (Patt et al., 1974), many isolates capable of growth on methane have proven incapable of growth on conventional organic media (Whittenbury et al., 1970). Several factors may explain the lack of capacity to assimilate organic compounds such as an inhibition effect by these compounds (although balanced mixtures of amino acids can cancel the inhibition by one or the other amino acid, Smith and Hoare, 1977), the impermeability of the cell (e.g. Eccleston and Kelly, 1972) or the loss of enzymes from the main assimilation pathways (Theisen et al., 2005; Smith and Hoare, 1977). In obligate methane-oxidising gamma-proteobacteria, the chemical conversion of carbohydrates, lipids and proteins into $\mathrm{CO}_{2}$ and $\mathrm{H}_{2} \mathrm{O}$ for energy production is blocked at the level of the tricarboxylic acid (TCA) cycle, due to the concurrent absence of one of its key enzymes, $\alpha$-ketoglutarate dehydrogenase, and of isocitrate lyase and malate synthase from the glyoxylate shunt (Trotsenko, 1983). In some cases, succinyl CoA synthetase, another enzyme from the TCA cycle, is also missing, like in Thiobacillus denitrificans or M. capsulatus (Smith and Hoare, 1977). However, our finding that some 


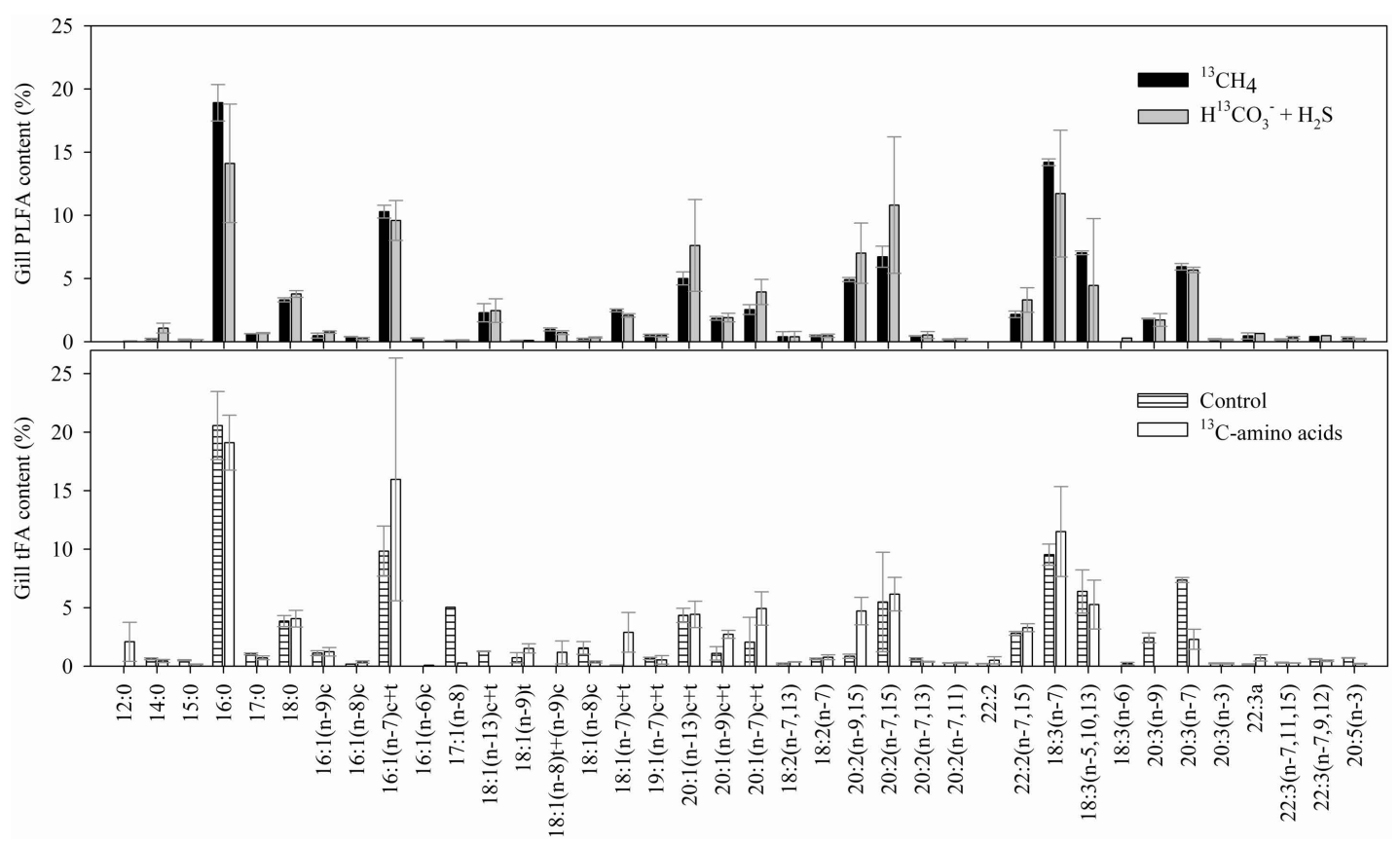

Fig. 4. Bathymodiolus azoricus gill tissue PLFA or tFA content $\left(n=3\right.$, average \pm standard deviation) after a 15 day supply with ${ }^{13} \mathrm{CH}_{4}($ black bars), or a 20 day supply with $\mathrm{H}^{13} \mathrm{CO}_{3}^{-}$in the presence of $\mathrm{H}_{2} \mathrm{~S}$ (grey bars), or with ${ }^{13} \mathrm{C}$-amino acids (white bars); striped bars represent control mussels.

of the MOB (16:1 $(n-8)$ and $(n-6))$ and SOX (12:0) symbionts biomarkers were labeled after incubation with ${ }^{13} \mathrm{C}$ amino acids indicates that the symbionts had at least access to acetyl coA (or acetate) produced during the degradation of the amino acids by the host, and/or that they have the capacity to absorb and metabolise external amino acids. Further experiments are needed to ascertain these hypotheses.

\section{Conclusions}

PLFA and total FA ${ }^{13} \mathrm{C}$-fingerprinting in Bathymodiolus azoricus gill tissues allowed us to trace the assimilation of ${ }^{13} \mathrm{C}$-enriched $\mathrm{HCO}_{3}^{-}$(in the presence of $\mathrm{H}_{2} \mathrm{~S}$ ) and $\mathrm{CH}_{4}$ into the endosymbionts and host. Based on the selective labeling pattern of PLFA in each of the experimental treatments we could establish qualitative FA profiles of MOB and SOX endosymbiotic bacteria living in association with $B$. azoricus. Additionally, carbon from dissolved free amino acids was found to be incorporated into host specific FA and also into some of the symbiont biomarkers.

The tracer uptake experiments in the present study could only be performed under conditions of atmospheric pressure. It therefore needs to be verified through future experiments whether or not the activated metabolic pathways are the same under high, in situ pressure conditions and atmospheric pressure. While more experimentation is needed to better understand the physiology of the ensosymbionts, this experiment has shown its usefulness for positioning the endosymbionts among described strains, as well as for the direct identification of the symbiont biomarkers, for which until now only assumptions had been made.

Acknowledgements. We thank especially C. Leal, M. Laranjo, L. Pires, V. Costa, R. Bettencourt and A. J. Cavagna and M. Korntheuer for assistance during experimental and analytical work. Our thanks also go to S. Duperron for his expert advise and to the Victor 6000 team, the crews of " $R / V$ Arquipélago" and "Pourquoi Pas?" and chief scientists of the MoMARETO cruise J. Sarrazin and P. M. Sarradin who were in charge of the cage deployments and recovery. Financial support for this research was provided by the EU project MoMARNET-FP6-RTN/2003/505026 and the Research Council of Vrije Universiteit Brussel. The EU Framework Contract No EVK3-CT1999-00003 (VENTOX) funded the cage system and partially LabHorta with the project DRCT M2.1.1/I/008/2005 LabHorta - Automation and Up-Grading of LabHorta - Technology for the exploration of marine molecules of deep-sea organisms (PRODESA). IMAR-DOP/UAç research activities are additionally supported through the pluri-annual and programmatic funding schemes of FCT (Portugal) and Azorean Regional Directorate for Science and Technology (DRCT, Azores, Portugal) as Research Unit \#531 and Associate Laboratory \#9.

Edited by: J. Middelburg

\section{References}

Abrajano, T. A., Murphy, D. E., Fang, J., Comet, P., and J. M. Brooks: ${ }^{13} \mathrm{C} /{ }^{12} \mathrm{C}$ ratios in individual fatty acids of marine 
mytilids with and without bacterial symbionts, Org. Geochem., 21, 611-617, 1994.

Barnathan, G.: Non-methylene-interrupted fatty acids from marine invertebrates: occurrence, characterization and biological properties, Biochimie, 91, 671-678, 2009.

Berg, J. M., Tymoczko, J. L., and L. Stryer: Carbon atoms of degraded amino acids emerge as major metabolic intermediates, in: Biochemistry, W. H. Freeman and Co., New York, 2002.

Bodelier, P. L. E., Bär Gillisen, M. J., Hordijk, K., Sinninghe Damsté, J. S., Rijpstra, W. I. C., Geenevasen, J. A. J., and Dunfield, P. F.: A reanalysis of phospholipid fatty acids as ecological biomarkers for methanotrophic bacteria, Int. Soc. Microb. Ecol. J., 3, 606-617, 2009.

Boschker, H. T. S., Nold, S. C., Wellsbury, P., Bos, D., de Graaf, W., Pel, R., Parkes, R. J., and Cappenberg, T. E.: Direct linking of microbial populations to specific biogeochemical processes by ${ }^{13}$ C-labeling of biomarkers, Nature, 392, 801-805, 1998.

Bowman, J. P., Sly, L. I., Nichols, P. D., and Hayward, A. C.: Revised taxonomy of the methanotrophs: description of Methylobacter gen. nov., emendation of Methylococcus, validation of Methylosinus and Methylocystis species, and a proposal that the family Methylococcaceae includes only the group I methanotrophs, Int. J. Syst. Bacteriol., 43, 735-753, 1993.

Colaço, A. and Santos, R. S. : LABHORTA, A Land-based laboratory for vent studies, in: Towards Planning of Sea-floor Observatory Programs for the MAR region (Proceedings of the II MoMAR Workshop), Arquipélago, Life and Marine Sciences, Supplement 3, XII, edited by: Santos, R. S., Escartin, J., Colaço, A., and Adamczewska, A., p. 36, 2002 b.

Colaço, A., Desbruyères, D., and Guezennec, J.: Polar lipid fatty acids as indicators of trophic associations in a deep-sea vent system community, Mar. Ecol., 28, 15-24, 2007.

Conway, N. and McDowell Capuzzo, J.: Incorporation and utilization of bacterial lipids in the Solemya velum symbiosis, Mar. Biol., 108, 277-291, 1991.

Cook, H. W.: Fatty acid desaturation and chain elongation in eukaryotes, in: Biochemistry of lipids, lipoproteins and membranes, edited by: Vance, D. E. and Vance, J. E., Elsevier Science, Amsterdam, 129-152, 1996.

Dedysh, S. N., Knief, C., and Dunfield, P. F.: Methylocella species are facultatively methanotrophic, J. Bacteriol., 187(13), 46654670, 2005.

Desbruyères, D., Biscoito, M., Caprais, J. C., Colaço, A., Comtet, T., Crassous, P., Fouquet, Y., Khripounoff, A., Le Bris, N., Olu, K., Riso, R., Sarradin, P. M., Segonzac, M., and Vangriesheim, A.: Variations in deep-sea hydrothermal vent communities on the Mid-Atlantic Ridge near the Azores plateau, Deep-Sea Res. Pt. I, 48(5), 1325-1346, 2001.

Dunstan, G. A., Volkman, J. K., and Barrett, S. M.: The effect of lyophilization on the solvent extraction of lipid classes, fatty acids and sterols from the oyster Crassostrea gigas, Lipids, 28, 937-944, 1993.

Duperron, S., Bergin, C., Zielinski, F., Blazejak, A., Pernthaler, A., McKiness, Z. P., DeChaine, E., Cavanaugh, C. M., and Dubilier, N.: A dual symbiosis shared by two mussel species, Bathymodiolus azoricus and Bathymodiolus puteoserpentis (Bivalvia: Mytilidae), from hydrothermal vents along the northern Mid-Atlantic Ridge, Environ. Microbiol., 8, 1441-1447, 2006.

Eccleston, M. and Kelly, D. P.: Assimilation and toxicity of exoge- nous amino acids in the methane oxidizing bacterium, Methylococcus capsulatus, J. Gen. Microbiol., 71, 541-554, 1972.

Fay, L. and Richli, U.: Location of double bonds in polyunsaturated fatty acids by gas chromatography-mass spectrometry after 4,4dimethyloxazoline derivatization, J. Chromatogr. A, 541, 89-98, 1991.

Fiala-Médioni, A., McKiness, Z. P., Dando, P., Boulegue, J., Mariotti, A., Alayse-Danet, A. M., Robinson, J. J., and Cavanaugh, C. M.: Ultrastructural, biochemical, and immunological characterization of two populations of the mytilid mussel Bathymodiolus azoricus from the Mid-Atlantic Ridge: evidence for a dual symbiosis, Mar. Biol., 141, 1035-1043, 2002.

Guckert, J. B., Antworth, C. P., Nichols, P. D., and White, D. C.: Phospholipid, ester-linked fatty acid profiles as reproducible assays for changes in prokaryotic community structure of estuarine sediments, FEMS Microbiol. Lett., 31, 147-158, 1985.

Kawashima, H. and Ohnishi, M.: Fatty Acid Compositions of Various Tissue Lipids in the Marine Bivalves, Megangulus venulosus and Megangulus zyonoensis, from Coastal Waters of Hokkaido, Northern Japan, J. Oleo Sci., 52, 309-315, 2003.

King, J. D., White, D. C., and Taylor, C. W.: Use of lipid composition and metabolism to examine structure and activity of estuarine detrital microflora, Appl. Environ. Microb., 33, 1177-1183, 1977.

Knief, C., Lipski, A., and Dunfield, P. F.: Diversity and activity of methanotrophic bacteria in different upland soils, Appl. Environ. Microb., 69, 6703-6714, 2003.

Kramer, J. K. G., Hernandez, M., Cruz-Hernandez, C., Kraft, J., and Dugan, M. E. R.: Combining results of two GC separations partly achieves determination of all cis and trans 16:1, 18:1, 18:2 and 18:3 except CLA isomers of milk fat as demonstrated using Ag-ion SPE fractionation, Lipids, 43, 259-273, 2008.

Lewis, T., Nichols, P. D., and McMeekin, T. A.: Evaluation of extraction methods for recovery of fatty acids from lipid-producing microheterotrophs, J. Microbiol. Meth., 43, 107-116, 2000.

McCaffrey, M. A., Farrington, J. W., and Repeta, D. J.: Geochemical implications of the lipid composition of Thioploca spp. from the Peru upwelling region $-15^{\circ} \mathrm{S}$, Org. Geochem., 14, 61-68, 1989.

Nakagawa, S. and Takai, K.: Deep-sea vent chemoautotrophs: diversity, biochemistry and ecological significance, FEMS Microbiol. Lett., 65, 1-14, 2008.

Nichols, P. D., Smith, G. A., Antworth, C. P., Hanson, R. S., and White, D. C.: Phospholipid and lipopolysaccharide normal and hydroxy fatty acids as potential signatures for methane-oxidising bacteria, FEMS Microbiol. Lett., 31, 327-335, 1985.

Patt, T. E., Cole, G. C., Bland, J., and Hanson, R. S.: Isolation and characterization of bacteria that grow on methane and organic compounds as sole sources of carbon and energy, J. Bacteriol., 120, 955-964, 1974.

Payne, D. J., Warren, P. V., Holmes, D. J., Ji, Y., and Lonsdale, J. T.: Bacterial fatty-acid biosynthesis: a genomics-driven target for antibacterial drug discovery, Drug. Discov. Today, 6(10), 537544, 2001.

Perner, M., Bach, W., Hentscher, M., Koschinsky, A., GarbeSchönberg, D., Streit, W. R., and Strauss, H.: Short-term microbial and physico-chemical variability in low-temperature hydrothermal fluids near $5^{\circ} \mathrm{S}$ on the Mid-Atlantic Ridge, Environ. Microbiol., 11(10), 2526-2541, 2009. 
Pimenov, N. V., Kaliuzhnaia, M. G., Khmelenina, V. N., Mitiushina, L. L., and Trotsenko, I. A.: Utilization of methane and carbon dioxide by symbiotrophic bacteria in gills of Mytilidae (Bathymodiolus) from the Rainbow and Logachev hydrothermal fields on the Mid-Atlantic Ridge, Microbiology, 71(5), 587-594, 2002.

Pond, D. W., Bell, M. V., Dixon, D. R., Fallick, A. E., and Sargent, J. R.: Stable-Carbon-Isotope composition of fatty acids in hydrothermal vent mussels containing methanotrophic and thiotrophic bacterial endosymbionts, Appl. Environ. Microb., 64, 370-375, 1998.

Precht, D. and Molkentin, J.: Identification and quantitation of cis/trans $\mathrm{C} 16: 1$ and C17:1 fatty acid positional isomers in German human milk lipids by thin-layer chromatography and gas chromatography/mass spectrometry, Eur. J. Lipid Sci. Tech., 2000, 102-113, 2000.

Riou, V., Halary, S., Duperron, S., Bouillon, S., Elskens, M., Bettencourt, R., Santos, R. S., Dehairs, F., and Colaço, A.: Influence of $\mathrm{CH}_{4}$ and $\mathrm{H}_{2} \mathrm{~S}$ availability on symbiont distribution, carbon assimilation and transfer in the dual symbiotic vent mussel Bathymodiolus azoricus, Biogeosciences, 5, 1681-1691, doi:10.5194/bg-5-1681-2008, 2008.

Riou, V., Colaço, A., Bouillon, S., Khripounoff, A., Dando, P., Mangion, P., Chevalier, E., Korntheuer, M., Santos, R. S., and Dehairs, F.: Mixotrophy in the deep sea: a dual endosymbiotic hydrothermal mytilid assimilates dissolved and particulate organic matter, Mar. Ecol. Progr. Ser., 405, 187-201, 2010.

Sepers, A. D. J.: The utilization of dissolved organic compounds in aquatic environments, Hydrobiologia, 52, 39-54, 1977.

Smith, A. J. and Hoare, D. S.: Specialist phototrophs, lithotrophs, and methylotrophs: unity among a diversity of prokaryotes, Bacteriol. Rev., 41, 419-448, 1977.

Sorokin, D. Y., Tourova, T. P., Braker, G., and Muyzer, G.: Thiohalomonas denitrificans gen. nov., sp. nov. and Thiohalomonas nitratireducens sp. nov., novel obligately chemolithoautotrophic, moderately halophilic, thiodenitrifying Gammaproteobacteria from hypersaline habitats, Int. J. Syst. Evol. Microbiol., 57, 1582-1589, 2007.
Spiridonova, E. M., Kuznetsov, B. B., Pimenov, N. V., and Tourova, T. P.: Phylogenetic characterization of endosymbionts of the hydrothermal vent mussel Bathymodiolus azoricus by analysis of the 16S rRNA, $c b b L$, and pmoA genes, Microbiology, 75(6), 694-701, 2006.

Theisen, A. R. and Murrell, J. C.: Facultative Methanotrophs Revisited, J. Bact., 187(13), 4303-4305, 2005.

Trotsenko, Y. A.: Metabolic features of methane- and methanolutilizing bacteria, Acta Biotechnol., 3, 269-277, 1983.

Tunlid, A. and White, D. C.: Biochemical analysis of biomass, community structure, nutritional status, and metabolic activity of microbial communities in soil, in: Soil Biochemistry, Vol. 7, edited by: Stotzky, G. and Bollag, J. M., Marcel Dekker, INC, New York, 229-262, 1992.

Vestal, J. R. and White, D. C.: Lipid analysis in microbial ecology: quantitative approaches to the study of microbial communities, BioScience, 39, 535-541, 1989.

White, D. C., Davis, W. M., Nickels, J. S., King, J. D., and Bobbie, R. J.: Determination of the sedimentary microbial biomass by extractible lipid phosphate, Oecologia, 40, 51-62, 1979.

Whittenbury, R., Phillips, K. C., and Wilkinson, J. F.: Enrichment, isolation and some properties of methane utilizing bacteria, J. Gen. Microbiol., 61, 205-218, 1970.

Won, Y., Hallam, S. J., O’Mullan, G. D., and Vrijenhoek, R. C.: Cytonuclear disequilibrium in a hybrid zone involving deep-sea hydrothermal vent mussels of the genus Bathymodiolus, Mol. Ecol., 12, 3185-3190, 2003.

Wright, S.: A Nutritional Role for Amino Acid Transport in FilterFeeding Marine Invertebrates, Amer. Zool., 22, 621-634, 1982.

Zhang, C. L., Huang, Z., Cantu, J., Pancost, R. D., Brigmon, R. L., Lyons, T. W., and Sassen, R.: Lipid Biomarkers and Carbon Isotope Signatures of a Microbial (Beggiatoa) Mat Associated with Gas Hydrates in the Gulf of Mexico, Appl. Environ. Microb., 71(4), 2106-2112, 2005.

Zhukova, N. V.: Biosynthesis of Non-methylene-interrupted dienoic Fatty Acids from $\left[{ }^{14} \mathrm{C}\right]$ Acetate in Molluscs, Biochim. Biophys. Acta, 878, 131-133, 1986. 